\title{
Character Education Values in Indonesian Children's Poems
}

\author{
Tri Mulyono ${ }^{1}$, Basukiyatn ${ }^{2}$, Sri Mulyati ${ }^{3}$ \\ Universitas Pancasakti Tegal \\ \{upstrimulyono@gmail.com\}
}

\begin{abstract}
Character education values really need to be taught at school. Indonesia has long been doing less productive habits for shaping an excellent country. Those bad habits are getting up late, scrawling graffiti, disliking hard work, a waste of electricity, and disliking reading. Based on those, the problems were how the character education values in Indonesian children's poems are and how the map of character education values in Indonesian children's poems is meant. This research was done descriptively with primary data which is a compilation of Indonesian children's poems created by AbdurahmanFaiz, entitled "I am the Love Poem". Based on the research, it is known that character education values found in the poem compilation are faith, care, cooperation, persistence, amarma'ruf, nahimunkar, tenacity, reflection, vision, and patience.
\end{abstract}

Keywords: Character Education Values, Indonesian Children's Poems

\section{Introduction}

Hidayatullah (2010: 17) states that character education is absolutely necessary for Indonesia. It is because Indonesia has long been doing various less productive habits for shaping an excellent country. Sugiarto (2009: 11-13) mentions 55 trivial habits that can destroy the progress of this country. The trivial habits meant are as regards personal, environmental, economic, and social aspects. The habits in regard to personal aspect are underestimating time, getting up late, coming late to work, lack of discipline, and procrastination. The ones concerning environmental aspect are smoking everywhere, littering, graffiti or vandalism, improper advertising in the streets, nails on trees, and exaggerated plastic consumption. The ones related to economic aspect are consumptive behavior, showing off, a waste of electricity, envy of others' properties, uncreative thinking. The ones concerning social aspect are disliking reading, nepotism, bribery, the politics of return of capital, forgetting the history, and gang fight.

Act no 14 Year 2005 about the National Education System (Sisdiknas) chapter 3 mentions that "the national education functions to develop ability and to shape dignified nation's nature and civilization in order to make the nation life intelligent, for the development of potential education participants so that they become people of faith and of piety to God, people of noble morality, of sensibility, of knowledge, of skills, of creativity, of independence, of democracy and of responsibility". So, the purpose of the national education is not only to create people of intelligence, but also of character. 
In Sarumpaet (2001: 12) White states that character building is the most important effort ever given to human. It is considered as the most important because shaping people of good morality is the main purpose of education, both education at households or at schools. This is in line with the opinion of Santoso (1981: 33), which is that the purpose of every pure education is to shape strong and firm self-esteem to students so that someday they can be people of independence.

Noor (2011) mentions that character education can run effectively when done on the basis of literature. It is because literature can shape child's character, can be used to instill religious values, and can be harnessed to give role models. According to Lichona (1991) character education is the education to shape personality through morality education, where the results are visible in one's real actions, which are good behavior, honesty, responsibility, respect for others' rights, and hard work. It is no wonder if later various studies about character education in literature works appear like, for example, the ones done by Sudigdo and Agustina (2013), Waluyo (2013), Widyorini and Sinaga (2017), Hinta (2017), and Subrata.

Apparently, nothing of the existent studies is considered interesting, mainly, if character education values are taught at schools. For example, a study by Sudigdo and Agustina (2013) was done to folklores with a title "Character Education on the Basis of the Folklores as the Formation of Students' Characters". Those folklores are too long and less actual to be taught in primary schools.

The study by Waluyo (2013) was done to a drama script, entitled "Character Education to A Drama Story, Tale and Others by Arifin C. Noor". This study is also less interesting because the source is a drama script for adults' consumption. In addition, it is because the study was done to works by Arifin C. Noor, which in general contain existentialism. The study by Widyorini and Sinaga (2017) was done to a myth, entitled "Character Education Values in the Myth of Ngobaran Shore in GunungKidul". Besides being less actual, myths are less interesting if taught for primary students.

The study by Hinta (2017) was done to a folklore, entitled "The Character Education Values of 'Lahilote', A Folklore from Gorontalo". Meanwhile, the study by Subrata (2017) was done to Javanese poems, entitled "Character Learning Using the Javanese 'TembangMacapat' in Primary School". Javanese tembangmacapat is one of Javanese song forms. Javanese songs are less interesting if taught to primary students because the songs are too old and unknown by the students.

Considering that, I think that character value learning to primary students is appropriately done by children's poem medium. Children's poems are shorter and also more contextual. Besides, the content of children's poems is considered more appropriate for the spirit of primary students because they are written by primary students themselves. Children's poems are part of children's literature. According to Huck et al. (1987: 6) children's literature is literature works (books) which writing places children's perspective as the center of attention. By Nurgiyantoro(2005: 2-12), children's literature is the literature which gives pleasure and understanding of life, is the image and metaphor of life, in which children as the center of imagery have limitations in content and form, is oral and written literature, is read by children of 1-12 years old, and is written by children and adults.

Based on that, I would study character education values in a children's poem compilation by AbdurahmanFaiz (2005) entitled "I am The Love Poem". In this, the problems were (1) how the character education values in the poem compilation "I am the Love Poem" are? and (2) how the map of character education values in the poem compilation "I am the Love Poem" is? 


\section{Research Methodology}

This research was done by using descriptive method and objective approach. Primary data which is poem lines were obtained from a poem compilation created by AbdurahmanFaiz, entitled "I am the Love Poem". The data was collected by using read-and-note technique. In this poem compilation, there are 20 poem titles, namely, "My Father and Mother", "Harry Potter", "For Teacher", "Ode of the Ants", "Siti and Udin in the Street", "Muhammad I Yearn for", "My Prayer Today", "Mother Went to America", "Mother's Way", "From An Iraqi Child in My Dream, for Bush", "The Seven Wounds on My Birthday", "Who Wants to be President?", "Dreams in the Highway", "Prayer for All Garbage Men in the World", "Father", "Where is My Gratitude", "The Child of Television", "The Ballad of Sri and Nirmala", "The Poet", "My Best Friend is Book", and "The Anti-War Poem".

\section{Research Result and Discussion}

The research result shows that character education values in Indonesian children's poems are faith, care, cooperation, persistence, amarma'ruf, nahimunkar, tenacity, reflection, vision, and patience.

\subsection{Faith}

The character education value "faith" is found in four poem titles. The four poem titles meant are "My Father and Mother", "Muhammad I Yearn for", "Prayer for All Garbage Men in the World", and "Where is My Gratitude". In the poem entitled "My Father and Mother", for example, there is the value "faith".

Mother

you are

the moon dancing

in my chest

Father

you are

the sun that warms

my heart

Father and Mother

I love both of you

as I

love the heaven

May God kiss Father and Mother

in His beautiful garden

someday

In the poem above, the character education value is shown on verse IV, on line I: /May God kiss Father and Mother/. That line shows that the writer believes God exists. 


\subsection{Care}

The character education value "care" is also found in Indonesian children's poems. In Indonesian children's poems, the character education "care" is found in two poem titles, which are "Harry Potter" and "For Teacher". In the Indonesian children's poem entitled "Harry Potter", for example, there is the character education value "care". The character education value "care" is shown in this following quotation: //Have you found/the most secret potion/so that all people in the world/can love one another/.

\subsection{Cooperation}

Cooperation is a character education value found in Indonesian children's poems. The character education value "cooperation" is found in a poem entitled "Ode of the Ants". In the poem entitled "Ode of the Ants", the character education value "cooperation" is shown on verse IV as follows: /Nothing brings us down/we keep on walking/everywhere earning a living/no feelings of hostility/hand in hand for eternity/until we die//.

\subsection{Persistence}

Persistence is a character education value also found in Indonesian children's poems. In Indonesian children's poems, the character education value is found in three poem titles. The three poem titles are "Siti and Udin in the Street", "The Seven Wounds on My Birthday", and "Dreams in the Highway". In the poem entitled "Siti and Udin in the Street", for example, the character education value is shown on verse VII: //Morning until night/smiling in a sweat/greeting gentlemen and gentlewomen/for pennies//.

\subsection{Amar Ma'ruf}

The character education value "amarma'ruf" in Indonesian children's poems is found in three poem titles. The three poem titles are "My Prayer Today", "The Poet", and "My Best Friend is Book". In the poem entitled "My Prayer Today", for example, the character education value is shown in this following quotation: //My God/give me Your time/so I grow on the path of love/and sow/along the path of my father and mother/along my Indonesian way/along the path towards You/Amen//.

\subsection{Tenacity}

The character education value "tenacity" is also found in Indonesian children's poems. On Indonesian children's poems, the character value "tenacity" is found in a poem entitled "Mother Went to America" as it is shown on the last verse: //And I asked to God/so that Mother was always protected/Mother smiled and hugged me/she tenaciously went with hijab around her head/she said: God is the Only Protector//.

\subsection{Reflection}

The character education value "reflection" is found in a poem entitled "The Mother's Way". In this poem, someone reflects his or her mother's priceless affection. This quotation shows that thing: //Mother/you are the one who guides me/to the way of butterflies//. 


\subsection{NahiMunkar}

The character education value "nahimunkar" or an effort to prevent bad deeds is also found in Indonesian children's poems. In Indonesian children's poems, nahimunkar is found in a poem entitled "From An Iraqi Child in My Dream, for Bush", "The Poet", and "The AntiWar Poem". In the poem entitled "From An Iraqi Child in My Dream, for Bush", for example, there is the character education value "nahimunkar" as follows: //Why did you let the children taste suffering/those bullets were speaking to our bodies/in languages most poignant//.

\subsection{Vision}

Vision is included as a character education value found in Indonesian children's poems. In Indonesia children's poems, the character education value is found in a poem entitled "The Child of Television" as it is shown in this quotation: //At school teacher asked/about dreams/and while yawning for long/we answered/we wanted to be people/most useful for this country/as ever advised/by our parents, teachers, officials, politicians, ulama, celebrities/on television//.

\subsection{Patience}

The character education value "patience" is found in a poem entitled "Father" as it is shown in this following quotation: //As deep as the sea, as vast as the skies/love cannot always be measured/so it is that father disentangles time/shedding his sweat and longing/for me//. The map of character education values in Indonesian children's poems is shown on this following Table 1.

\begin{tabular}{clc}
\multicolumn{3}{c}{ Tabel 1. The Map Of Character Education Values } \\
\hline No. & Character Education Values & Number \\
\hline 1 & Faith & 4 \\
2 & Persistence & 3 \\
3 & Amar Ma'ruf & 3 \\
4 & Nahimunkar & 3 \\
5 & Care & 2 \\
6 & Cooperation & 1 \\
7 & Tenacity & 1 \\
8 & Reflection & 1 \\
9 & Vision & 1 \\
10 & Patience & 1 \\
& Number & 10 \\
\hline
\end{tabular}

\section{Conclusion}

Based on the explanation above, it can be concluded that the character education values in Indonesian children's poems are faith, care, cooperation, persistence, amarma'ruf, tenacity, reflection, nahimunkar, vision and patience. Those values especially are found in an Indonesian children's poem by AbdurahmanFaiz (2005) entitled "I am the Love Poem". 


\section{References}

[1] Hunt, Peter. 1995. Critics, Theory and Children's Literature. Combridge Massachusetts: Blackwell.

[2] K, S, Yudiono, 2009. Pengkajian Kritik Sastra Indonesia. Jakarta: Grasindo.

[3] Lazar, Gillian. 1993. Literature and Language Teaching. New York: Combridge University Press.

[4] Littlewood, William T. 1987. "Literature in the School Foreign-Language Course" dalam Christopher Brumfit dan Ronald Carter. 1987. Literature and Language Teaching. Oxford: Oxford University Press.

[5] Mulyono, Tri. 2018. "Struktur dan Nilai Estetika Puisi Anak Indonesia". Semarang: Disertasi.

[6] Nugraha, Setya Tri. 2010. "Penggalian Nilai-nilai Budaya Melalui Karya Sastra dalam Pembelajaran BIPA" dalam M Badrus Siroj. 2010. "Kumpulan Artikel Ilmiah Pembelajaran Bahasa Indonesia untuk Penutur Asing (BIPA)”. Semarang: Universitas Negeri Semarang.

[7] Nurgiyantoro, Burhan. 2005. Sastra Anak Pengantar Pemahaman Dunia Anak. Yogyakarta: Gadjah Mada University Press.

[8] Sarumpaet, Riris K-Toha. 1976. Bacaan Anak-anak suatu Penyelidikan Pendahuluan ke dalam Hakikat, Sifat, dan Corak Bacaan Anak-anak serta Minat Anak pada Bacaannya. Jakarta: Pstaka Jaya.

[9] Winarni, Retno. 2014. Kajian Sastra Anak. Yogyakarta: Graha Ilmu. 